\title{
The contrasting roles of water and dust in controlling daily variations in radiative heating of the summertime Saharan heat low
}

\author{
John H. Marsham ${ }^{1,2}$, Douglas J. Parker ${ }^{2}$, Martin C. Todd ${ }^{3}$, Jamie R. Banks ${ }^{4}$, Helen E. Brindley ${ }^{4}$, \\ Luis Garcia-Carreras ${ }^{2}$, Alexander J. Roberts ${ }^{2}$, and Claire L. Ryder ${ }^{5}$ \\ ${ }^{1}$ National Centre for Atmospheric Science (NCAS), Leeds, UK \\ ${ }^{2}$ School of Earth and Environment, University of Leeds, Leeds, UK \\ ${ }^{3}$ Department of Geography, University of Sussex, Brighton, UK \\ ${ }^{4}$ Space and Atmospheric Physics Group, The Blackett Laboratory, Imperial College, London, UK \\ ${ }^{5}$ Department of Meteorology, University of Reading, Reading, UK \\ Correspondence to: John H. Marsham (j.marsham@leeds.ac.uk)
}

Received: 13 May 2015 - Published in Atmos. Chem. Phys. Discuss.: 16 July 2015

Revised: 11 February 2016 - Accepted: 20 February 2016 - Published: 17 March 2016

\begin{abstract}
The summertime Sahara heat low (SHL) is a key component of the West African monsoon (WAM) system. Considerable uncertainty remains over the relative roles of water vapour and dust aerosols in controlling the radiation budget over the Sahara and therefore our ability to explain variability and trends in the SHL, and in turn, the WAM. Here, new observations from Fennec supersite-1 in the central Sahara during June 2011 and June 2012, together with satellite retrievals from GERB, are used to quantify how total column water vapour (TCWV) and dust aerosols (from aerosol optical depth, AOD) control day-to-day variations in energy balance in both observations and ECWMF reanalyses (ERA-I). The data show that the earth-atmosphere system is radiatively heated in June 2011 and 2012. Although the empirical analysis of observational data cannot completely disentangle the roles of water vapour, clouds and dust, the analysis demonstrates that TCWV provides a far stronger control on TOA net radiation, and so the net heating of the earthatmosphere system, than AOD does. In contrast, variations in dust provide a much stronger control on surface heating, but the decreased surface heating associated with dust is largely compensated by increased atmospheric heating, and so dust control on net TOA radiation is weak. Dust and TCWV are both important for direct atmospheric heating. ERA-I, which assimilated radiosondes from the Fennec campaign, captures the control of TOA net flux by TCWV, with a positive correlation $(r=0.6)$ between observed and modelled TOA net radiation, despite the use of a monthly dust climatology in
\end{abstract}

ERA-I that cannot capture the daily variations in dustiness. Variations in surface net radiation, and so the vertical profile of radiative heating, are not captured in ERA-I, since it does not capture variations in dust. Results show that ventilation of the SHL by cool moist air leads to a radiative warming, stabilising the SHL with respect to such perturbations. It is known that models struggle to capture the advective moistening of the SHL, especially that associated with mesoscale convective systems. Our results show that the typical model errors in Saharan water vapour will lead to substantial errors in the modelled TOA energy balance (tens of $\mathrm{W} \mathrm{m}^{-2}$ ), which will lead to errors in both the SHL and the WAM.

\section{Introduction}

The Sahara lies under the descending branch of the Hadley circulation and during summer the intense solar heating combined with the arid environment leads to large sensible surface heat fluxes and the formation the Saharan heat low (SHL). This increases the pressure gradient from the Gulf of Guinea to the Sahara, driving the West African monsoon (WAM); and variations in the SHL modify the WAM on timescales from days to decades (Thorncroft and Blackburn, 1999; Sultan and Janicot, 2003; Parker et al., 2005; Peyrillé and Lafore, 2007; Biasutti et al., 2009; Lavaysse et al., 2009, 2010; Chauvin et al., 2010; Xue et al., 2010; Martin and Thorncroft, 2014; Martin et al., 2014; Dong and Sut- 
ton, 2015). There is a shortage of routine observations in the SHL and substantial disagreements exist even between analyses (Marsham et al., 2011; Roberts et al., 2015). The Fennec project aimed to better quantify processes governing the Saharan atmosphere (Washington et al., 2012; Ryder et al., 2015) and deployed an observational supersite-1 close to the climatological centre of the SHL (Marsham et al., 2013a).

The radiative budget of the Sahara is significantly modulated by variations in clouds, dust, and water vapour. Charney (1975) shows how the high albedo and dry atmosphere can lead to a top-of-atmosphere (TOA) net radiative cooling in July, with heating via subsidence, proposing a positive feedback where dry soils with little vegetation generate high albedo, favouring atmospheric descent and low rainfall. The dry atmosphere means that water vapour provides a key control in the longwave with vapour at all levels affecting top-of-atmosphere (TOA) outgoing longwave (Allan et al., 1999; Brindley and Harries, 1998). Evan et al. (2015) suggest that the increasing temperatures within the SHL over the past 30 years, key to the recovery of the Sahel from drought, are driven by longwave impacts of increasing water vapour, in the "Saharan Water Temperature" feedback and Dong and Sutton (2015) propose a greenhouse-gas driven increase with a feedback through water vapour. Shallow clouds on top of the deep dry boundary layer (Cuesta et al., 2009) occur around $20 \%$ of the time over the Sahara, with mid-level clouds reducing net surface shortwave and increasing net surface longwave in the Sahel (Stein et al., 2011; Bouniol et al., 2012). Dust absorbs and emits longwave radiation (Haywood et al., 2005) and scatters and absorbs shortwave (Ryder et al., 2013; Banks et al., 2014). At the TOA, and over the bright Sahara, dust induces a warming as its longwave effects dominate its shortwave effects (Balkanski et al., 2007; Yang et al., 2009). Operational models use either prognostic dust or dust climatologies, but struggle to capture variations in summertime dust, partly as cold-pool outflows from convection (haboobs) provide a key uplift mechanism that is missing in operational models that use parameterised moist convection (Marsham et al., 2011, 2013a; Heinold et al., 2013).

At low levels the Sahara is cooled by advection from neighbouring moister and cooler regions, including the WAM to the south. Representing the monsoon is a challenge to models, partly because of the representation of convection, in particular its diurnal timing and cold pools; the diurnal timing of Sahelian moist convection affects the pressure gradient driving the monsoon, modulating the flux of water vapour from the Sahel to the Sahara and hence rainfall over the Sahel (Marsham et al., 2013b; Birch et al., 2014). Furthermore cold pools form a significant component of the monsoon (Marsham et al., 2013b) and also ventilate the Sahara from the Atlas in the north (Emmel et al., 2010); most temperature and humidity biases in the Met Office global model at the Fennec supersite-1 during June 2011 were caused by missing cold pool advection (Garcia-Carreras et al., 2013). Similarly ventilation of the Sahara by the Atlantic Inflow in- volves mesoscale flows that are a challenge for global models (Grams et al., 2010; Todd et al., 2013). Since clouds, water vapour and dust are all important to the Sahara's radiative energy balance, such model errors in convection, clouds, haboobs and advection of water vapour will all affect modelled radiative energy balances and hence climate.

There is a clear need to establish the controls on the radiation budget over the Sahara and evaluate models. In this paper we use observations of surface radiative fluxes from Fennec supersite- 1 in the central Sahara and retrievals of TOA fluxes from satellite data to investigate how dust and water together control the day-to-day variations in energy balance over the Fennec supersite-1 in the summertime SHL region, and how this is represented in ERA-Interim (ERA-I) reanalysis. Results in Sect. 3 show that TCWV (total column water vapour) and AOD are correlated and we cannot completely isolate the effects of either TCWV or dust. However, TCWV and AOD have sufficiently independent variations, and sufficiently distinct impacts at solar and infrared wavelengths, which conform with physical principles, that the results give unique insights into their contrasting roles in the central Sahara. Section 2 describes methods, Sect. 3 presents results, Sect. 4 contains discussion and conclusions are in Sect. 5 .

\section{Method}

We use data from Fennec supersite-1 in the central Sahara, located at Bordj-Badji Mokhtar (BBM) at $21.4^{\circ} \mathrm{N} 0.9^{\circ} \mathrm{E}$ (in the very south of Algeria, close to the triple point of Algeria, Mali and Niger), close to the SHL's climatological centre and the dust maximum (Marsham et al., 2013a), together with corresponding values from ERA-Interim (Dee et al., 2011), and satellite TOA fluxes (Harries et al., 2005; Dewitte et al., 2008). These satellite TOA fluxes are produced using a narrow to broad band conversion of SEVIRI (Spinning Enhanced Visible and Infrared Imager) radiance measurements. These are scaled by co-located GERB (Geostationary Earth Radiation Budget experiment) measurements and converted into broadband fluxes measurements at a horizontal resolution of $3 \times 3$ SEVIRI pixels $(0.32-4$ microns in the shortwave, and 4-100 microns in the longwave). This enhancement gives a spatial resolution of $9 \mathrm{~km}$ at nadir, compared with the $45 \mathrm{~km}$ of the native GERB. These observed fluxes are from clear and cloudy skies, but we also use the European Organisation for the Exploitation of Meteorological Satellites' MPEF (Meteorological Product Extraction Facility) cloud mask as a simple measure of cloud cover. ERA-Interim uses aerosol climatologies so it cannot capture day-to-day variations in dust. Radiosonde data from the Fennec supersite were assimilated into ERA-I, which will have improved its representation of the thermodynamic profile (see GarciaCarreras et al., 2013, for impacts of assimilation of Fennec radiosondes on the Met Office global forecast model). 
Fennec data are from intensive observation periods (IOPs) in June 2011 and 2012, when a Cimel sun photometer provided aerosol optical depths (AODs) at $675 \mathrm{~nm}$, a Kipp \& Zonen radiometer mounted at $2 \mathrm{~m}$ provided measurements of broad-band radiative fluxes and 3- to 6-hourly radiosonde observations were available (Marsham et al., 2013a). The sunphotometer is part of the AERONET program (Holben et al., 1998) and cloud-screened AOD retrievals are only available during the day. Level-2 AOD data are not available for 2012 since not all data meet level-2 requirements. However, the $0.675 \mathrm{~nm}$ AODs are still reliable. We therefore use level-2 data for 2011 and level-1.5 for 2012, noting that using only 2011 data does not affect our conclusions. We use the radiosondes to compute column water vapour from the surface to $300 \mathrm{hPa}$ (a height consistently reached by the radiosondes), which we refer to simply as "total column water vapour (TCWV)". During June 2011 BBM was regularly cooled by nocturnal monsoon flows and embedded cold pools giving substantial variability in TCWV (Marsham et al., 2013a), and qualitatively similar weather events were observed during June 2012.

In order to study the day-to-day variations in the energy budget, we average all data to their daily means. Complete surface flux data were only available for 11 days in June 2011 (9, 10, 18-20, 23-27, 30 June) and 25 days in June 2012 (all except 4, 16-18, 30 June). Some dates had short data gaps (around 2 hours on 2 days, but otherwise an hour or less) and these gaps were interpolated across in order to include 7, 17, 21, 22 June 2011 and 16-17 June 2012. This gave an improved range of AODs, albeit with increased uncertainties in surface fluxes. Fluxes from these days with some interpolation are marked by squares in Figs. 1 to 4 , and the effects of interpolation are discussed in Sect. 3, where it is seen that results from these days are physically consistent with other data from days without interpolation. The surface flux data from Kipp and Zonen radiometers have slightly different spectral ranges to the satellite-borne GERB: Kipp and Zonen are 0.3 to $2.8 \mu \mathrm{m}$ in the shortwave and 4.5 to $42 \mu \mathrm{m}$ in the longwave, whilst GERB is 0.32 to $4 \mu \mathrm{m}$ and 4 to $100 \mu \mathrm{m}$. This means that the surface-based Kipp and Zonen can miss up to $3.5 \mathrm{~W} \mathrm{~m}^{-2}$ net shortwave atmospheric heating as would be seen by GERB and up to $3.8 \mathrm{~W} \mathrm{~m}^{-2}$ of the net longwave as would be seen by GERB (Banks et al., 2014). This introduces errors of up to $4 \mathrm{~W} \mathrm{~m}^{-2}$ in our inferred direct atmospheric radiative heating rates, but does not affect our analysis and conclusions, which is focused on the controls on the variability of these rates, rather than their absolute values.

Sun-photometer AODs were available from 8 June 2011 (with no observations on 13 June) and 1 to 28 June 2012 (with no observations on 17-19 June). Radiosondes were available from 8 June 2011 and 1 to 26 June 2012. The number of observations contributing to the daily mean is variable for AODs, since observations are only made when it is cloud free, but all days except one had at least eight AOD observations and the daily mean AOD range of 0.2 to 2.7 is similar

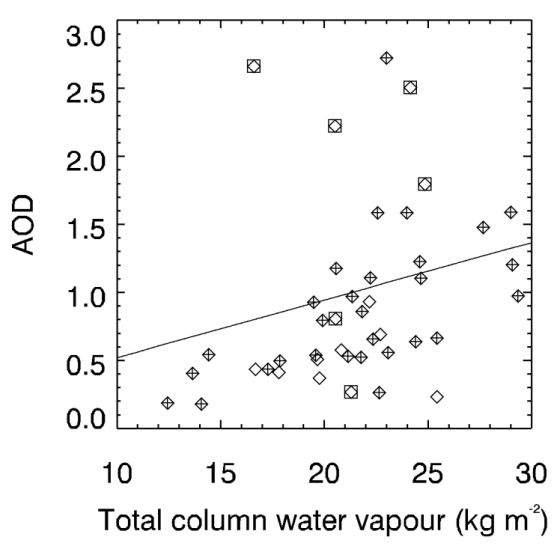

Figure 1. Daily means of TCWV and AOD, pluses show days with complete surface data, squares show days with some interpolation (see Sect. 2). Diamonds show all data points (including days with no surface-flux data).

to that of the observation range in AODs (0.2 to 3.9) and the diurnal cycle in AOD is weak (Marsham et al., 2013a; Banks et al., 2014). Overall this gave 36 days with surface data, observed AOD and observed TCWV and 44 days with TCWV and AOD.

\section{Results}

In order to determine how the changing amounts of water and dust over BBM affect the changing radiative heating at the surface, TOA and within the atmosphere we analyse relationships between the daily means of key variables, using both observed quantities and the equivalent from ERA-I at the location of BBM. ERA-I uses a climatological AOD field and so cannot capture the observed daily variability in AOD. This, in effect, represents a quasi-control experiment for dust variability. Net fluxes are defined as downward, with increased net downward flux corresponding to increased shortwave heating or reduced longwave cooling. All correlations and slopes of linear regression lines discussed are listed in Table 1 (correlations in bold are significant at the $90 \%$ level). Relationships are shown using days where surface data are available (referred to as "Good surface data"), and for all available data ("All data") where surface flux data are not required. The regressions are very similar whichever data set is used and values in the text are for "Good surface data", unless otherwise noted. The effect of subsampling is small for ERA-I, showing that general lessons can be drawn from the observational data, despite the limited time-span of the data set. Similarly, for both June 2011 and 2012 analysed water vapour at 850 and $925 \mathrm{hPa}$ and AODs from MISR, Deep blue (Terra and Aqua) and OMI are all within 1 standard deviation of their mean values (not shown) and there is no indication that the weather regimes affecting BBM in these periods were anomalous. 
Table 1. Gradients of best-fit straight lines (i.e. regression coefficients) for listed relationships, values in [ ] are normalised by standard deviation of TCWV or AOD. Values in ( ) are correlation coefficients (bold values are significant at $90 \%$ level). For ERA-I observed AODs are used. Standard deviation in TCWV in ERA-I $=4.7 \mathrm{~kg} \mathrm{~m}^{-2}$ ( 4.5 for "All data"). For observations $4.7 \mathrm{~kg} \mathrm{~m}^{-2}$ ( 4.4 for "All data"). Standard deviation in AOD for observations is 0.68 (0.65 in "All data").

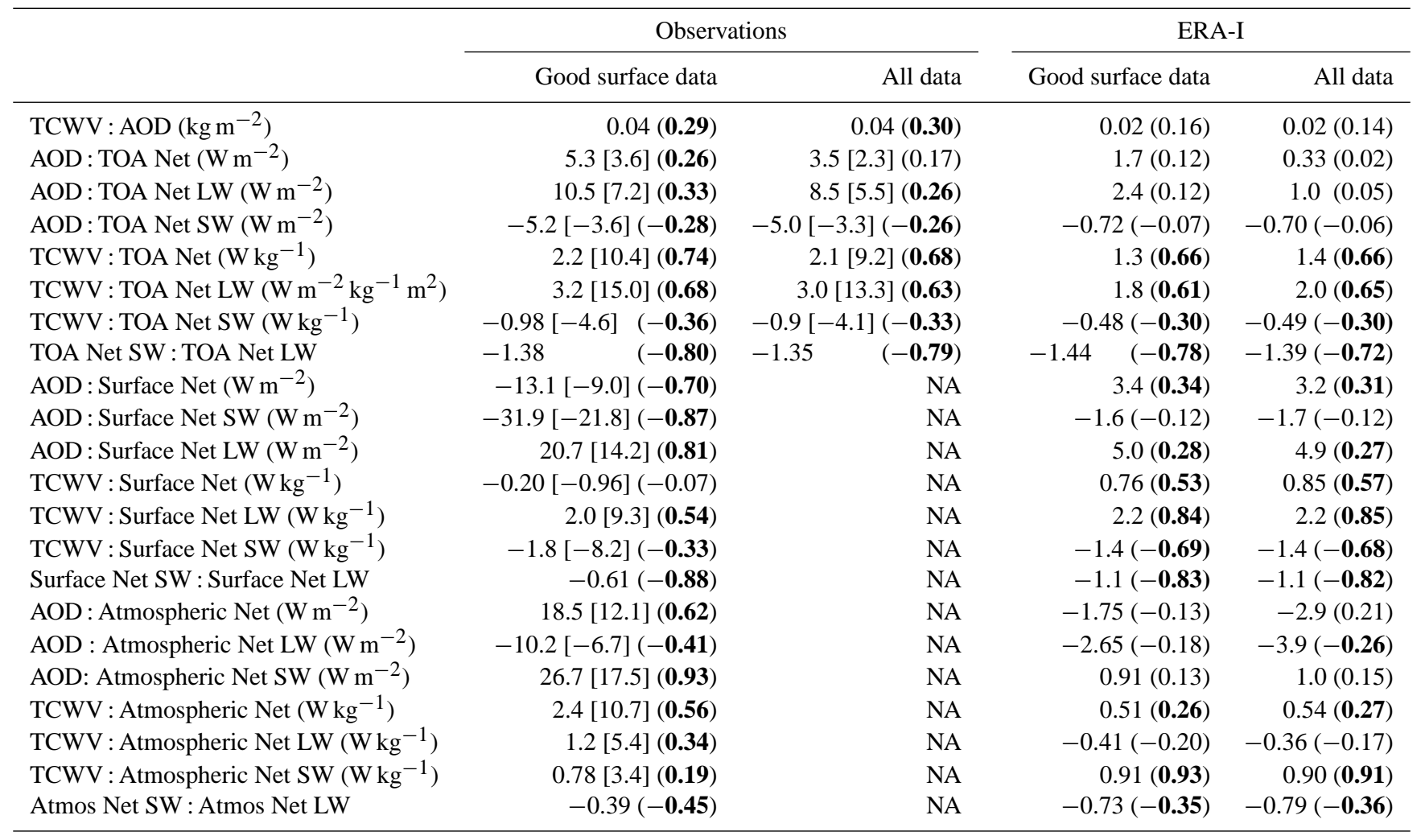

There are correlations between dust and water (discussed below) which mean that effects of either cannot be completely isolated from the other, but nevertheless the approach allows identification of how variations in these variables affect radiative heating. Figure 1 shows that there is a significant tendency for more dust with more TCWV, although there are a few dry dusty days (correlation $=0.29$ ). The use of surface flux data with some interpolation (shown by squares) allows study of more days with high AODs. The mechanisms underlying this correlation are understood: Marsham et al. (2013a) shows how moist monsoon surges from the south are associated with dust at BBM. This is because the moist surges are associated with both dusty haboobs and moist nocturnal low-level jets (LLJs) that together dominate the dust uplift at BBM in June 2011 (Marsham et al., 2013a; Allen et al., 2013). The association between dust and water vapour is consistent with Fig. 16 in Marsham et al. (2013a), which shows a statistical link between AOD and cloud cover at BBM. Intense dust uplift does sometimes occur in dry air, however, mainly in the dry Harmattan LLJs (Marsham et al., 2013a; Allen et al., 2013).

\subsection{Control of TOA net radiation by water (TCWV) and aerosols (AOD)}

Daily mean net TOA radiation is always positive (i.e. downwards) and has a mean value of $26 \mathrm{~W} \mathrm{~m}^{-2}$, i.e. there is warming of the earth-atmosphere system throughout the period (Fig. 2a). Net heating varies between around 0 and $70 \mathrm{~W} \mathrm{~m}^{-2}$, or approximately 0 to $1.2 \mathrm{~K} \mathrm{day}^{-1}$ if the heating were distributed over the $5 \mathrm{~km}$ deep boundary layer.

There is a significant correlation of 0.74 between TCWV and TOA net radiation. Figure 2 a shows that TOA net downward radiation increases with TCWV (and associated dust and cloud), with a regression coefficient of $+2.2 \mathrm{~W} \mathrm{~kg}^{-1}$. This is a result of a $3.2 \mathrm{~W} \mathrm{~kg}^{-1}$ increase in TOA net longwave with TCWV in observations (Fig. S1a in the Supplement), from water vapour, clouds (and associated dust) reducing TOA outgoing longwave. This longwave TCWV effect dominates the decrease in net shortwave with increased water vapour ( $-0.98 \mathrm{~W} \mathrm{~kg}^{-1}$, Fig. S1d), due to water vapour and associated clouds and dust. The correlations are strongest between TCWV and TOA net or longwave radiation (both 0.74 and 0.68$)$, rather than TOA shortwave $(-0.36)$, since the water vapour directly affects the longwave, while much 

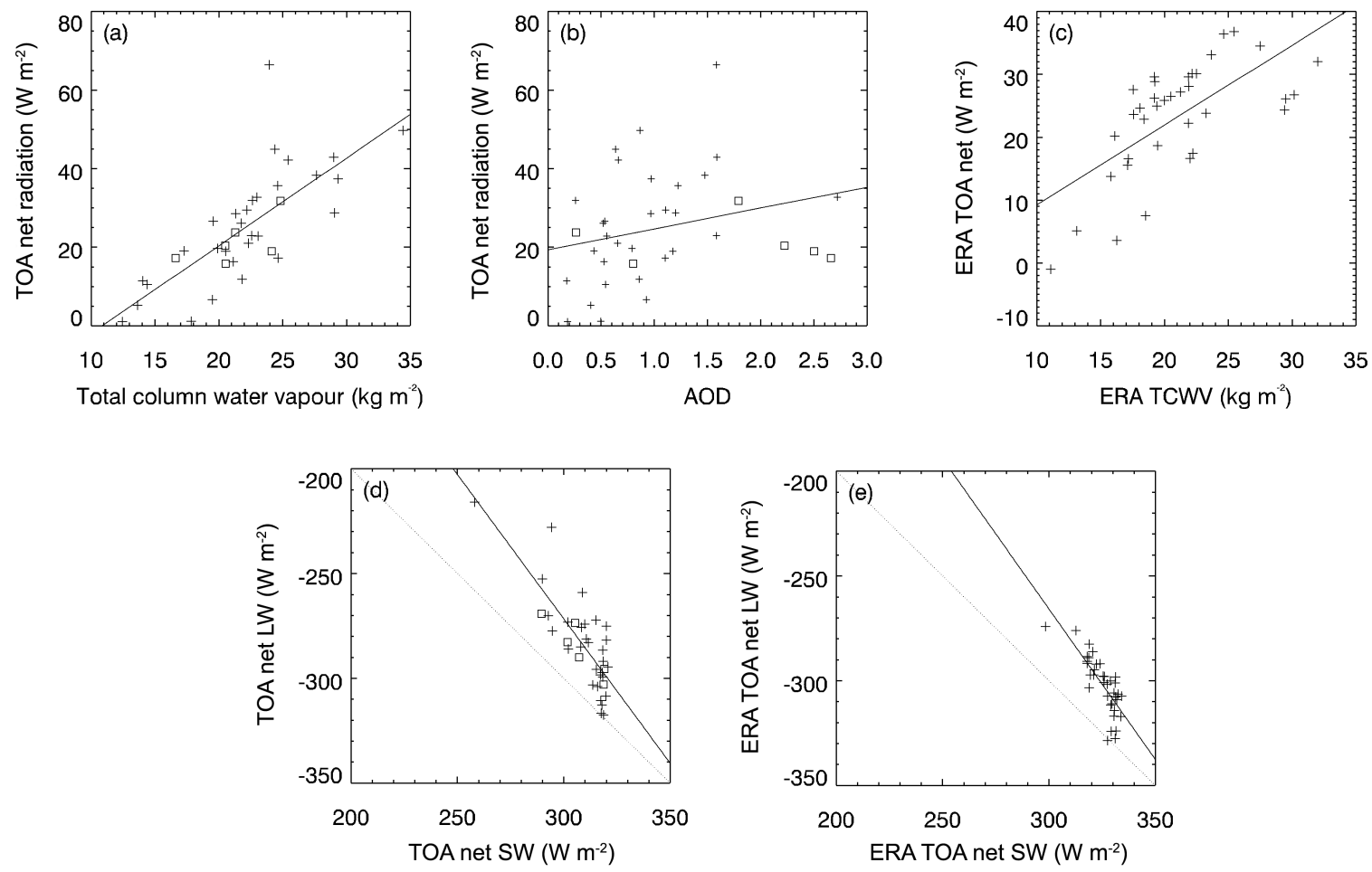

Figure 2. TOA fluxes, with symbols as in Fig. 1, showing daily means for days with surface data. Dotted lines in (d) and (e) have a gradient of -1 .

of the shortwave effects of TCWV are indirect, occurring via associated clouds and dust.

The correlation between AOD and TOA net radiation (Fig. 2b) is much weaker than between TCWV and TOA net radiation (0.26 compared with 0.74$)$. Figure $2 \mathrm{~b}$ shows that TOA net radiation increases with $\mathrm{AOD}\left(5.3 \mathrm{~W} \mathrm{~m}^{-2}\right.$ per AOD, comparable with Balkanski et al., 2007), but this relationship is complex and its magnitude decreases to $3.5 \mathrm{~W} \mathrm{~m}^{-2}$ if all available data are used (with a correlation of 0.17 ). The increase in net TOA radiation with AOD occurs because the increase in TOA longwave $\left(+10.5 \mathrm{~W} \mathrm{~m}^{-2}\right.$ per AOD) dominates the decrease in TOA net shortwave $\left(-5.2 \mathrm{~W} \mathrm{~m}^{-2}\right.$ per AOD; Fig. S1b and e). The observed net effect of dust at TOA and the dominance of the longwave for this effect are both consistent with previous studies (Balkanski et al., 2007; Yang et al., 2009). Banks et al. (2014) show that in clear sky the diurnal mean effect of dust at BBM is warming in the shortwave. Therefore the observed reduced shortwave heating associated with dust reported in Fig. 2 is likely a result of cross correlation of AOD and cloud. This cloud, as well as the water vapour and dust, reduces outgoing longwave, leading to a warming. The effects of AOD and TCWV variations on radiation normalised by the standard deviation $(\sigma)$ in either AOD or TCWV (Table 1, values in square brackets) show that the variance in TCWV has a much larger effect on TOA net radiation $\left(10.4 \mathrm{~W} \mathrm{~m}^{-2}\right.$ per $\left.\sigma\right)$ than the variance in $\operatorname{AOD}\left(3.6 \mathrm{~W} \mathrm{~m}^{-2}\right.$ per $\sigma$, or $2.3 \mathrm{~W} \mathrm{~m}^{-2}$ if "All data" are used), i.e. most day-to-day variations in net TOA radiation are mostly controlled by TCWV, not AOD.

Figure $2 \mathrm{~d}$ shows daily net shortwave heating is always greater than net longwave cooling (the Earth-atmosphere system is warming in June). Daily variations in shortwave are anti-correlated with variations in longwave such that as daily net TOA shortwave decreases, the net longwave increases (correlation of -0.80 ). In Fig. 2d, if the gradient is less than -1 , reducing the net shortwave will increase the net flux. The observed gradient is -1.4 , i.e. days with net shortwave reduced by combinations of dust and cloud are associated with increased longwave heating (i.e. reduced longwave cooling) from the water vapour, dust and cloud that more than compensates for the decreased shortwave heating, resulting in greater net heating on these days. Figure $2 \mathrm{~d}$ shows how there is greater variance in daily longwave cooling than shortwave warming and therefore, although they are coupled, variations in longwave cooling make the larger contribution to variations in TOA net radiation.

\section{TCWV and aerosol effects at TOA in ERA-I}

The ERA-I regression coefficients for TOA net radiation with TCWV of $1.3 \mathrm{~W} \mathrm{~kg}^{-1}$ (1.4 $\mathrm{W} \mathrm{kg}^{-1}$ for all data) is similar to that observed $\left(2.2 \mathrm{~W} \mathrm{~kg}^{-1}, 2.1 \mathrm{~W} \mathrm{~kg}^{-1}\right.$ for all data, Fig. $2 \mathrm{c}$ and a). ERA-I captures the sign of correlations of both TOA net longwave and shortwave with TCWV, although it un- 
derestimates the magnitude of the regression coefficients for both $\left(1.8 \mathrm{~W} \mathrm{~kg}^{-1}\right.$ in longwave for ERA-I, compared with the $3.2 \mathrm{~W} \mathrm{~kg}^{-1}$ observed, and $-0.48 \mathrm{~W} \mathrm{~kg}^{-1}$ in shortwave for ERA-I compared with the $-0.98 \mathrm{~W} \mathrm{~kg}^{-1}$ observed; Fig. S1c and $\mathrm{f}$ ). As observed, reduced net shortwave increases TOA net flux in ERA-I (Fig. 2e, gradient of -1.4).

Even though it does not account for the daily variations in dust, ERA-I captures much of the day-to-day variations in TOA net variation (correlations with observations are 0.62 and 0.73 for "All data" and "Good surface data", not shown). Table 1 shows that the regression coefficients for ERA-I fluxes with observed AODs are of the correct sign: this suggests that some of the observed trends with AOD are due to associated water vapour and cloud (captured at least to some extent by ERA-I), rather than dust. This is consistent with the lower correlations between observed AOD and observed TOA net flux (0.26) than between observed TCWV and observed TOA net flux (0.74), discussed in the previous section.

The differences in the effects of TCWV in ERA-I and in observations are likely because of both errors in clouds in ERA-I and its lack of variability in dust. Detailed validation of model clouds over the bright dusty Sahara is challenging and beyond the scope of this paper. Here, we note that ERA captures day-to-day variations of mean cloud fraction (correlation with MPEF cloud mask of 0.56), but mean cloud fraction in ERA-I is 0.22, much less than the MPEF value of 0.53 , although this value is likely biased high by dust. Surface albedo in ERA-I is very close to observed, but TOA upward shortwave in ERA-I is about $15 \mathrm{~W} \mathrm{~m}^{-2}$ less than in observations (although daily maxima in these values are similar, not shown). These comparisons with data both support the hypothesis that ERA-I underestimates cloud cover (consistent with Dolinar et al., 2015, Fig. 4). The underestimate of the regression coefficient of TOA net longwave with TCWV in ERA-I compared with observations (1.8 compared with $3.2 \mathrm{~W} \mathrm{~kg}^{-1}$ ) is consistent with this suspected underestimation of cloud cover in ERA-I and also the lack of dust associated with TCWV reducing outgoing longwave (Haywood et al., 2005). However, in ERA-I the underestimation of the magnitude of the regression coefficient of TOA net longwave with TCWV (1.8 compared with $\left.3.2 \mathrm{~W} \mathrm{~kg}^{-1}\right)$ and shortwave with TCWV $\left(-0.48\right.$ compared with $\left.-0.98 \mathrm{~W} \mathrm{~m}^{-2}\right)$ compensate to some extent give a trend in TOA net radiation with TCWV of $1.3 \mathrm{~W} \mathrm{~kg}^{-1}$ in ERA-I, close to the $2.2 \mathrm{~W} \mathrm{~kg}^{-1} \mathrm{ob}-$ served.

\subsection{Control of surface net radiation by TCWV and AOD}

At the surface there is a strong and significant decrease in net radiation with increasing AOD (Fig. 3b) with a regression coefficient of $-13.1 \mathrm{~W} \mathrm{~m}^{-2}$ per AOD. This is a result of compensating longwave and shortwave effects, with the shortwave effect being largest: Table 1 (and Fig. S2e) shows $-31.9 \mathrm{~W} \mathrm{~m}^{-2}$ surface net shortwave per AOD, with dust re- ducing solar heating at the surface (largely compensated by heating the atmosphere above, comparing with $-5.2 \mathrm{~W} \mathrm{~m}^{-2}$ TOA net shortwave per AOD, Sect. 3.3). Table 1 (Fig. S2b) shows $+20.7 \mathrm{~W} \mathrm{~m}^{-2}$ surface net longwave per AOD, i.e. dust, together with the water vapour and cloud associated with the dust, warms the surface in the longwave, but unlike at TOA this does not compensate fully for the shortwave effects. The effects of AOD on net, shortwave and longwave fluxes are consistent between the days with some interpolated values (asterisks) and other days (pluses).

TCWV decreases surface net radiation by $0.20 \mathrm{~W} \mathrm{~kg}^{-1}$ (Fig. 3a). This is a balance of $+2.0 \mathrm{~W} \mathrm{~kg}^{-1}$ from the longwave and $-1.8 \mathrm{~W} \mathrm{~kg}^{-1}$ from the shortwave, i.e. it is a small difference between two large numbers (Fig. S2a and d). Impacts of TCWV on surface net heating are therefore a subtle balance of water vapour, clouds and associated dust. If variations in surface net radiation with AOD and TCWV are normalised by the standard deviation in AOD or TCWV, variability in AOD is seen to dominate the variations in surface net radiation (square brackets in Table 1). For the impacts of TCWV, the days with some interpolated values at first appear to be inconsistent with other days (Figs. 3a, S1a, d), but this is due to the high AODs for these days, the effects of which are consistent with other data (Figs. 3b, S2be, e).At the surface, although the observed shortwave and longwave variations are anti-correlated (coefficient $=-0.88$ ), they cancel to a much lesser extent than at TOA. Figure $3 \mathrm{~d}$ shows how decreased shortwave leads to increased net longwave, but this does not tend to compensate fully (gradient of -0.61), so decreased shortwave gives decreased net surface radiation. As such, daily variability in surface net radiation at BBM is influenced more by variability in the shortwave than the longwave. Again data from days with some interpolation of surface fluxes (squares) are consistent with other days (pluses).

The observed increase in surface net longwave with TCWV of $2.0 \mathrm{~W} \mathrm{~kg}^{-1}$ is within the range of 1.0 to $3.0 \mathrm{~W} \mathrm{~kg}^{-1}$ obtained by Evan et al. (2015) for Tamanrasset from observations, analyses and radiative transfer modelling. In summer at Tamanrasset TCWV might be expected to correlate with AOD as it does at BBM, and dust and clouds associated with TCWV in reality, but missing or under-estimated in analyses and radiative transfer modelling, may account for the greater sensitivity of surface net longwave to TCWV in observations compared with radiative transfer modelling and analyses, noted by Evan et al. (2015). The BBM value of $2.0 \mathrm{~W} \mathrm{~kg}^{-1}$ is slightly lower than the diurnal-mean observational value of $3.0 \mathrm{~W} \mathrm{~kg}^{-1}$ for Tamanrasset obtained by Evan et al. (2015), which may reflect the greater prevalence of clouds at the high-altitude Tamanrasset site, where mountains trigger moist convection (Birch et al., 2012). The BBM results also suggest that although the increases in net surface longwave with TCWV shown by Evan et al. (2015) could largely be compensated by coincident decreases in net surface shortwave (as at BBM), this is not expected at TOA, 

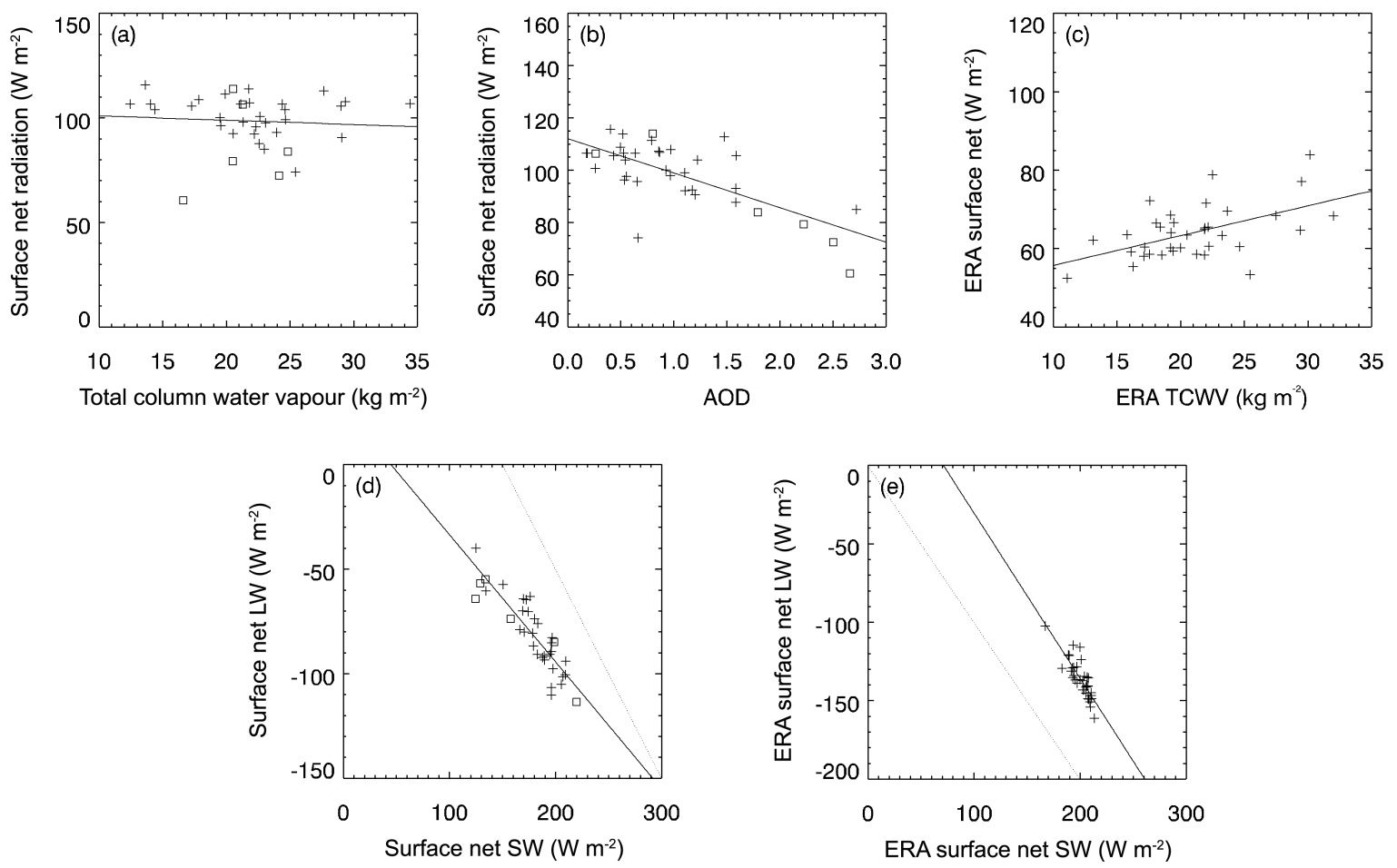

Figure 3. As Fig. 2, but for surface fluxes.

supporting the proposed role by Evan et al. (2015) of water vapour in warming the SHL.

\section{Effects of TCWV and AOD at the surface in ERA-I}

Figure 3c shows that, in contrast with observations (Fig. 3a), ERA-I always produces an increase in net surface radiation with increasing TCWV $\left(+0.76 \mathrm{~W} \mathrm{~kg}^{-1}\right.$, compared with $-0.20 \mathrm{~W} \mathrm{~kg}^{-1}$ ). Figure $3 \mathrm{e}$ (gradient -1.1 ) shows that at the surface in ERA-I, unlike in observations, decreased net shortwave is always compensated by increased net longwave (i.e. reduced longwave cooling). This occurs since in ERA-I greater water vapour leads to greater net surface longwave (i.e. reduced longwave cooling, Fig. S2c), without the associated dust to reduce the net surface shortwave (Fig. S2f): the net surface radiation in ERA-I depends largely on surface longwave, whereas in observations it depends largely on the shortwave. As a result, ERA-I, which uses a monthly dust climatology, fails to capture day-to-day variations in surface net radiation, producing no correlation (0.02) with observations.

Although it does not affect the regression coefficients of surface fluxes with TCWV and AOD discussed above, we note here that ERA-I surface net longwave is on average $55 \mathrm{~W} \mathrm{~m}^{-2}$ less than observed, and this is almost all from more upward longwave than observed (not shown). Due to the non-linear nature of thermal emission, the $13 \%$ error in upward longwave can be caused by only a $3 \%$ error in skin temperature (or from an error in emissivity). Maximum values of daily ERA-I surface net shortwave are similar to observed, but minima are higher, likely from missing dust and cloud. These two errors lead to surface net radiation being around $34 \mathrm{~W} \mathrm{~m}^{-2}$ lower in ERA-I than observed.

\subsection{Radiative heating of the atmosphere}

The TOA and surface fluxes are differenced to give the radiative flux convergence within the atmosphere, i.e. the direct radiative heating of the atmosphere (Fig. 4). As expected the atmosphere is cooling in the longwave and is heated in the shortwave. There are statistically significant positive correlations between both TCWV or AOD (which are themselves correlated, Fig. 1) and net radiative heating of the atmosphere (Fig. 4a and b). This is consistent with the results of Slingo et al. (2006) and Slingo et al. (2009) for dust over the Sahel. For AOD there is a strong correlation (0.93) with shortwave atmospheric heating (Fig. S3e, $26.7 \mathrm{~W} \mathrm{~m}^{-2}$ per AOD, comparable with Balkanski et al., 2007) that dominates the trend of net longwave heating with AOD (Fig. S3c, $-10.2 \mathrm{~W} \mathrm{~m}^{-2}$ ). There are significant increases in net shortwave and net longwave radiative heating of the atmosphere with increasing TCWV (Fig. S3a and d, Table 1). The longwave effect (Fig. S3a) is much less clear than it is at TOA or at the surface, since the effects at TOA and the surface (Figs. S1a and S2a) are similar (3.2 and $\left.2.0 \mathrm{~W} \mathrm{~m}^{-2}\right)$ and largely cancel each other. 

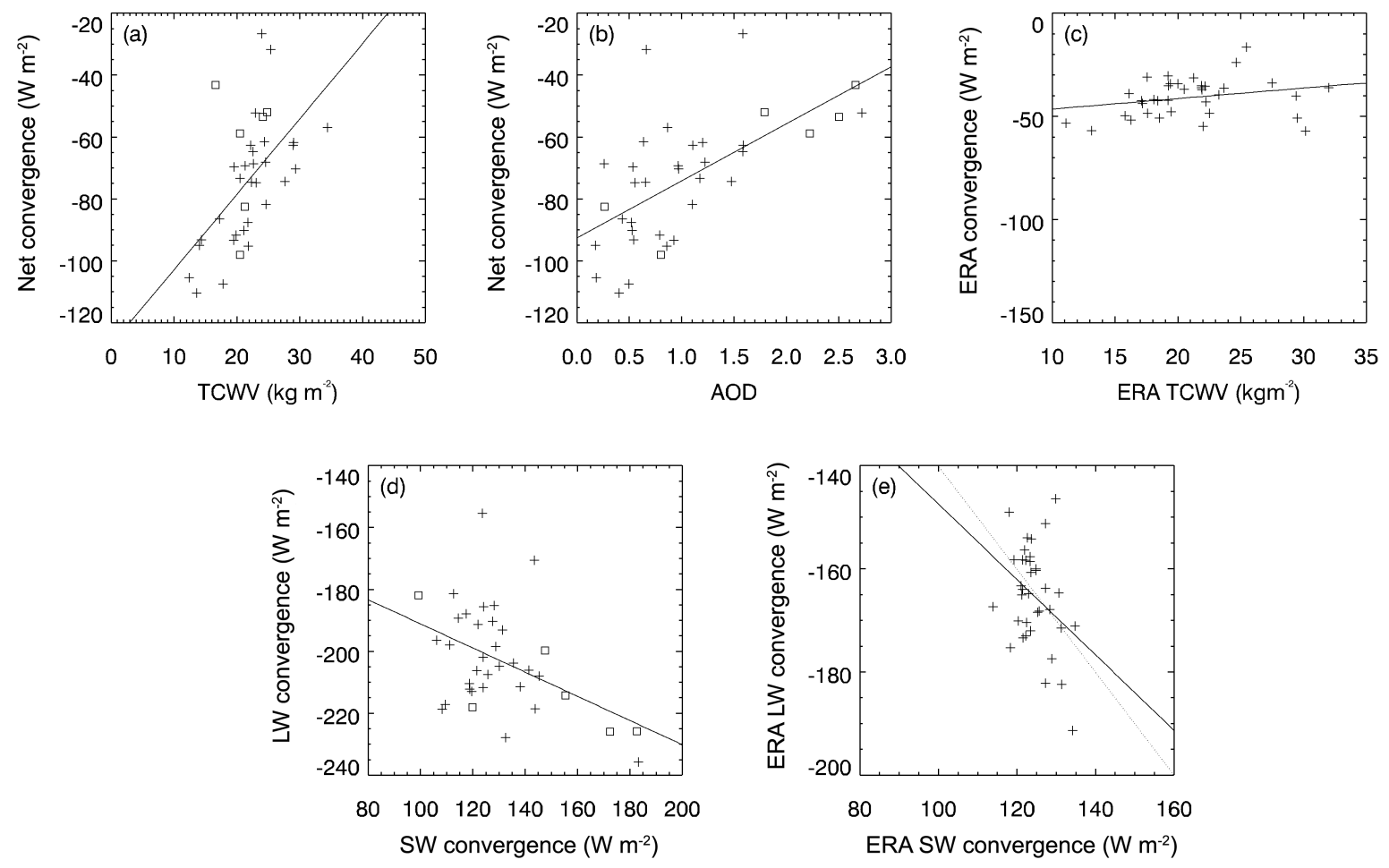

Figure 4. As Fig. 2, but for inferred atmospheric heating (TOA flux minus surface flux).

When trends with TCWV and AOD are normalised by the standard deviations in TCWV and AOD to allow comparison (results in square brackets in Table 1), effects of AOD dominate those from TCWV, but this is much more pronounced in the shortwave. The results therefore show significant shortwave heating of the atmosphere by dust (consistent with Banks et al., 2014), consistent with the large effect of AOD on surface net and surface net shortwave fluxes, with much smaller effects at TOA. Decreases in surface heating associated with dust are largely compensated by direct radiative heating of the atmosphere. The shortwave heating from TCWV (correlation coefficient of only 0.19) is similar to that in ERA (below and Fig. S3f) showing that is not just from associated dust, but from shortwave absorption by water (although points with unusually high shortwave heating are explained by AODs, Fig. S3d and e). Figure 4d shows how increasing longwave cooling of the atmosphere is more than compensated for by the corresponding increased shortwave heating (gradient $=-0.39$ ); atmospheric heating is largely controlled by effects of dust on the shortwave, whereas longwave atmospheric heating is much less variable.

\section{Atmospheric heating in ERA-I}

ERA gives weaker longwave atmospheric cooling than observed and therefore less net atmospheric cooling (Figs. 4c and S3c). Lacking the observed variability in dust, ERA has little variability in atmospheric shortwave heating, with almost no correlation of shortwave heating with observed AODs (Table 1). ERA has a significant increase in shortwave atmospheric heating with TCWV (Fig. S3f, $0.91 \mathrm{~W} \mathrm{~kg}^{-1}$ ) from absorption by water (similar to that observed, Fig. S3d, $0.78 \mathrm{~W} \mathrm{~kg}^{-1}$ ). While observations have a significant, but weak, positive correlation between TCWV and longwave atmospheric heating (Fig. S3a, 0.34), ERA has a weak insignificant negative correlation (Fig. S3c, -0.20). Effects are weak in both cases, since TOA and surface longwave fluxes both respond similarly to TCWV and ERA is of course lacking the variability in dust that correlates with TCWV and this may contribute to the difference. Despite the weak variation in shortwave atmospheric heating in ERA compared with observations, variations in shortwave dominate the variations in net atmospheric heating, giving increased net heating with increased TCWV (Fig. 4c). This is however much weaker than observed (Fig. 4a), since ERA has much less variability in net heating due to its use of a dust climatology.

\section{Discussion}

Since variability in water dominates day-to-day variability in net TOA heating it is crucial for models to capture the water content of the SHL. Small errors in TCWV, in the altitude of the water vapour, or in associated cloud, could cause errors in clear-sky longwave radiation comparable with the $50 \mathrm{~W} \mathrm{~m}^{-2}$ from dust seen in Haywood et al. (2005), or the 
20 to $40 \mathrm{~W} \mathrm{~m}^{-2}$ model bias that Allan et al. (2011) show can be removed by the inclusion of dust. This paper shows that $50 \mathrm{~W} \mathrm{~m}^{-2}$ TOA net longwave corresponds to around $16 \mathrm{~kg} \mathrm{~m}^{-2}$ water (based on the $3.2 \mathrm{~W} \mathrm{~kg}^{-1}$ dependence of TOA net longwave on TCWV, Table 1), roughly equivalent to $3 \mathrm{~g} \mathrm{~kg}^{-1}$ over the $5 \mathrm{~km}$ deep boundary layer. Roberts et al. (2015) show that root mean square differences in analyses of WVMR at $20^{\circ} \mathrm{N}$ in the Sahara are around $1.5 \mathrm{~g} \mathrm{~kg}^{-1}$, and show a case where differences between different analyses are around $4 \mathrm{~g} \mathrm{~kg}^{-1}$. Garcia-Carreras et al. (2013) show a global model mean bias of around $1 \mathrm{~g} \mathrm{~kg}^{-1}$ at Fennec supersite- 1 in June 2011 in the model first guess (3-to-6 h forecast), despite assimilation of the Fennec radiosoundings. Models struggle to capture monsoon flow that cools and moistens the SHL, in particular from cold pools (Marsham et al., 2013b; GarciaCarreras et al., 2013). This study shows that errors in fluxes of water vapour will lead to a compensating error of insufficient radiative heating from the absence of the moister air. Model errors in dust will affect the vertical distribution of heating and so also affect vertical mixing and dynamics.

The results give some insight into the Saharan BL energy budget during June over BBM. We show TOA net radiative heating of around $26 \mathrm{~W} \mathrm{~m}^{-2}$. There was an observed mean night-time cooling of around $4 \mathrm{~K}$ over an approximately $1 \mathrm{~km}$ depth every night (Marsham et al., 2013a), corresponding to around $50 \mathrm{~W} \mathrm{~m}^{-2}$ cooling (not all of this cooling is advective, some is radiative). To compensate for this cooling an additional warming of around $20 \mathrm{~W} \mathrm{~m}^{-2}$ is required. Daily entrainment of free-tropospheric air will raise the BL top, which is lowered by subsidence to give, in the long term, a constant BL top. We can estimate the heating rate of the $\mathrm{BL}$ either from entrainment or subsidence. The $24 \mathrm{~h}$ entrainment flux is perhaps $10 \mathrm{~W} \mathrm{~m}^{-2}$ ( $20 \%$ of the $100 \mathrm{~W} \mathrm{~m}^{-2}$ surface flux for $12 \mathrm{~h}$ ). The $24 \mathrm{~h}$ subsidence of a lid of $5 \mathrm{~K} / 100 \mathrm{~m}$ with $0.1 \mathrm{~m} \mathrm{~s}^{-1}$ is $5 \mathrm{~W} \mathrm{~m}^{-2}$. These simple estimates therefore leave a mis-match of around $10 \mathrm{~W} \mathrm{~m}^{-2}$, but show that all terms (net daytime radiative warming, net night-time radiative and advective cooling, entrainment of warm subsiding air) are all of a similar order of magnitude and significant.

Although modelling is needed to fully understand the observed effects of water vapour on the radiation, the observations show that monsoon surges at BBM are expected to have significant effects on radiative heating rates. In June 2011 BBM experienced sudden moistenings of up to around $5 \mathrm{~g} \mathrm{~kg}^{-1}$ (Fig. 5, Marsham et al., 2013a). If we assume that a value of $2.5 \mathrm{~g} \mathrm{~kg}^{-1}$ is more representative of the change over the $5 \mathrm{~km}$ deep Saharan BL (Fig. 3 in Marsham et al., 2013a, shows such monsoon surges tend to directly affect the lower half of the $5 \mathrm{~km}$ layer) this gives a TOA net radiative heating of around $28 \mathrm{~W} \mathrm{~m}^{-2}$ (based a TCWV of $12.5 \mathrm{~kg} \mathrm{~m}^{-2}$ and a dependence of net radiation on TCWV of $2.2 \mathrm{~W} \mathrm{~kg}^{-1}$, Table 1). If this heating is distributed over the $5 \mathrm{~km}$ deep Saharan BL it will result in a warming of around $0.5 \mathrm{~K} \mathrm{day}^{-1}$. It will therefore take days for the additional radiative warming to compensate for the cooling of a few de-

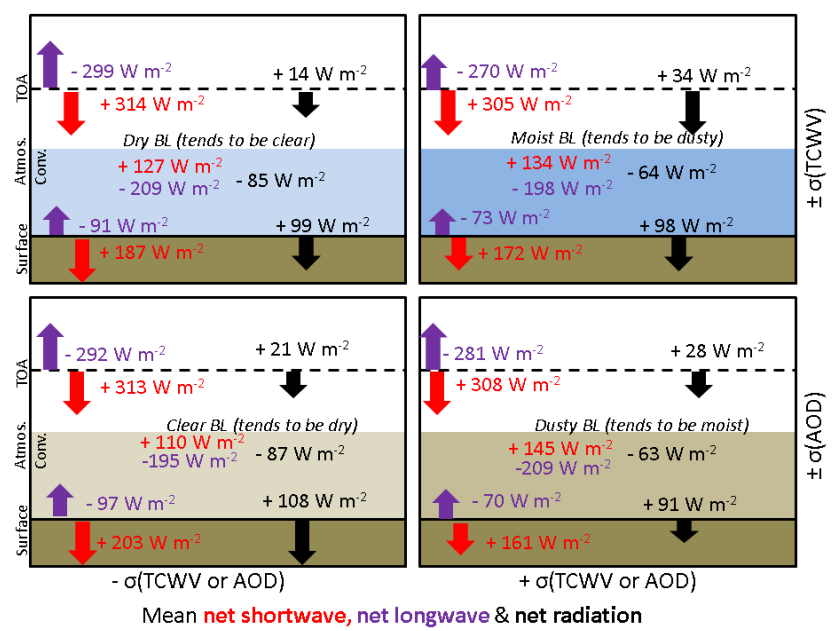

Figure 5. Schematic showing net radiation and implied tropospheric radiative heating, in situations where either TCWV (top row) or AOD (bottom row) is perturbed by plus or minus one standard deviation away from their mean state (right and left columns respectively). Moist atmospheres tend to be dusty and vice versa. Red numbers show net shortwave, purple numbers show net longwave and black show net radiation. TOA and surface heating are shown by plus signs with downward arrows. Values are shown at surface, TOA and for inferred atmospheric radiative heating ("Atmos. Conv."). Variance in TCWV has the dominant effect on net TOA radiation, while variance in AOD has the dominant effect on net surface radiation. Both TCWV and AOD are important for atmospheric heating rates.

grees experienced in such events. This "radiative rewarming timescale" may be one contributing factor (together with timescales such as those for advection \& mixing timescales and synoptic features such as African Easterly waves) to the variability of the 3-to-30-day variability of the SHL observed by Lavaysse et al. (2010).

The observed net radiative heating of the SHL region observed at BBM during June appears to contrast with Charney (1975), which shows heating from subsidence and TOA cooling from radiation for the Sahara in July. However, the Fennec supersite-1 is at the northern limit of the Inter Tropical Discontinuity and regularly receives cold moist air from the south (Marsham et al., 2013a). Charney (1975, Fig. 1) shows net TOA heating at the location of the Fennec supersite in July, with TOA net cooling only north of around $22^{\circ} \mathrm{N}$ (interestingly the TOA heating extends northeastwards over the Hoggar mountains, a region that favours northward extent of moist monsoon air; Cuesta et al., 2010). It is likely that further north away from the moistening from the monsoon the warmer drier atmosphere will give greater longwave cooling and a net radiative cooling, as shown by Charney (1975). This will be further investigated. 


\section{Conclusions}

We have used unique observations of surface energy balance, TCWV and AOD from the central Sahara in June, together with retrievals from GERB, to investigate controls on the day-to-day variations in radiative heating in the SHL region. TOA fluxes show that on average the earth-atmosphere system is warming $\left(26 \mathrm{~W} \mathrm{~m}^{-2}\right)$, the surface is warming $\left(98 \mathrm{~W} \mathrm{~m}^{-2}\right)$ and the atmosphere is cooling $\left(74 \mathrm{~W} \mathrm{~m}^{-2}\right)$, with the longwave cooling and the shortwave warming in each case. Although there are limits to the extent to which our empirical approach can disentangle the roles of dust, cloud and water vapour, largely due to correlations between these factors, the results provide new insight into their roles in controlling the radiative balance of the unique environment of the central Sahara (schematic in Fig. 5).

Water vapour and dust are observed to correlate in the central Sahara, likely due to the uplift of dust in monsoon surges and haboobs (Bou Karam et al., 2008; Marsham et al., 2008, 2013a). However, variations in water vapour (and associated variables such as temperature and cloud) and not variations in dust dominates day-to-day variability of TOA net radiation, and hence total heating of the earth-atmosphere system. ERA-I captures the observed variation in TOA net radiation (correlation with observations of around 0.65), despite a monthly dust climatology in ERA-I, which cannot capture day-to-day variations in dustiness. Variations in AOD dominate day-to-day variations in surface net radiation, which unsurprisingly are not captured in ERA-I. If effects from TCWV were simply due to correlated changes in AOD, or vice versa, these contrasting roles of TCWV and AOD at the TOA and surface would not be so distinct.

At TOA, on average, decreased shortwave heating gives greater net heating due to associated increases in longwave heating. ERA-I captures this and the overall impact of TCWV on TOA net radiation, with a mean increase in TOA net radiation with TCWV of $1.3 \mathrm{~W} \mathrm{~kg}^{-1}$ compared with $2.2 \mathrm{~W} \mathrm{~kg}^{-1}$ in observations. There are, however, compensating errors in the effects of TOA net shortwave and longwave with TCWV in ERA-I. ERA-I under-estimates the effects of TCWV on both TOA longwave and shortwave: it misses corresponding variations in dust and although it captures much of the effects of water vapour, it likely underestimates cloud (and significant uncertainties in analysed water vapour persist at BBM, even when radiosondes are assimilated, GarciaCarreras et al., 2013).

At the surface, dust (and associated water vapour and cloud) decreases net surface radiation in reality by around $13 \mathrm{~W} \mathrm{~m}^{-2}$ per AOD. Although increasing TCWV reduces the surface longwave cooling, the effect of TCWV on the net surface radiation is weak, variable and a subtle balance between the competing effects of water vapour, clouds and dust $\left(-0.2 \mathrm{~W} \mathrm{~kg}^{-1}\right)$. Unlike at the TOA, at the surface decreases in shortwave are on average not compensated by increases in longwave, leading to decreased net radiation with decreased shortwave. In contrast to the observations, ERAI gives greater net surface radiation with decreased surface shortwave: it is missing the effects of varying dust and can only capture the effects of water and cloud, likely underestimating cloud. This gives no correlation between ERA-I surface net radiation and that observed and a mean heating of $98 \mathrm{~W} \mathrm{~m}^{-2}$ compared with the observed value of $64 \mathrm{~W} \mathrm{~m}^{-2}$, due to an overestimation of surface downward shortwave in ERA-I. Differences between TOA and surface fluxes are used to infer atmospheric radiative heating. Effects from TCWV on these are significant, but they are more strongly controlled by AODs, since dust has a much greater effect on surface net radiation than TOA net radiation, while effects of TCWV on TOA and surface heating are more similar.

The results show that, when the SHL is cooled by cold moist air from its margins, the overall effect is to increase net TOA radiative heating, rewarming the SHL, a feedback which stabilises the system, by rewarming the cool air. This occurs in both reality and ERA-I. This ventilation by cold air is, however, normally accompanied by clouds and dust, which together reduce surface net radiation, which is not captured by ERA-I, as ERA-I is missing the variations in dust (and likely under-predicts cloudiness). As a result, even if ERA-I gives the correct TOA net radiation in response to water vapour, it fails to distribute this heating correctly in the vertical, with too much surface heating and insufficient boundary-layer heating. This will destabilise the boundarylayer profile compared with reality, affecting subsequent modelled dry and moist convection and therefore modelled transport of heat, momentum, water vapour and dust.

Improved modelling of the energy budget of the SHL region is needed in models to improve predictions of the WAM across timescales (e.g. Evan et al., 2015). The results show that it is important that models used for predictions can accurately capture the processes controlling the water vapour distribution over the Sahara, as well as the dust. This capability is currently questionable for water (Marsham et al., 2013b; Birch et al., 2014; Garcia-Carreras et al., 2013; Roberts et al., 2015), clouds (Roehrig et al., 2013; Stein et al., 2015) and dust (Evan et al., 2014), with many dust errors coming from moist convection (Marsham et al., 2011; Heinold et al., 2013). The results presented here therefore strongly motivate the need to improve the representation of advection of water vapour, clouds and convection in models.

\section{The Supplement related to this article is available online at doi:10.5194/acp-16-3563-2016-supplement.}

Acknowledgements. Fennec was funded by a NERC consortium grant (NE/G017166/1). We would like to thank Azzendine Saci, Abdelkader Ouladichir, Bouzianne Ouchene, Mohammed SalahFerroudj, Benyakoub Abderrahmane, Mohammmed Limam, 
and Diali Sidali (ONM) and Richard Washington (University of Oxford) for their contributions to setting up running the Fennec supersite, and indeed all at ONM Algeria for their patience and hospitality during Fennec. We would like to thank the AERONET PHOTONS team for their assistance with the Cimel Sun photometer. Acknowledgment is made to the FGAM (Facility for Ground-Based Atmospheric Measurement), NCAS (National Centre for Atmospheric Science) for the use of the sodar, lidar, and radiosonde units. ECMWF data were provided by the NCAS British Atmospheric Data Centre (BADC, http://badc.nerc.ac.uk/). We thank the Royal Meteorological Institute of Belgium for providing the GERB HR flux data. Marsham is a water@leeds research fellow part funded by ERC grant 257543 "Desert Storms", NCAS and the NERC SWAMMA project (NE/L005352/1). We would like to thank Amato Evan and two anonymous reviewers whose comments have improved the content and clarity of the paper.

Edited by: Y. Balkanski

\section{References}

Allan, R. P., Shine, K. P., Slingo, A., and Pamment, J. A.: The dependence of clear-sky outgoing long-wave radiation on surface temperature and relative humidity, Q. J. Roy. Meteor. Soc., 125, 2103-2126, 1999.

Allan, R. P., Woodage, M. J., Milton, S. F., Brooks, M. E., and Haywood, J. M.: Examination of long-wave radiative bias in general circulation models over North Africa during May-July, Q. J. Roy. Meteor. Soc., 137, 1179-1192, doi:10.1002/qj.717, 2011.

Allen, C. J. T., Washington, R., and Engelstaedter, S.: Dust emission and transport mechanisms in the central Sahara: Fennec ground-based observations from Bordj Badji Mokhtar, June 2011, J. Geophys. Res.-Atmos., 118, 6212-6232, doi:10.1002/jgrd.50534, 2013.

Balkanski, Y., Schulz, M., Claquin, T., and Guibert, S.: Reevaluation of Mineral aerosol radiative forcings suggests a better agreement with satellite and AERONET data, Atmos. Chem. Phys., 7, 81-95, doi:10.5194/acp-7-81-2007, 2007.

Banks, J. R., Brindley, H. E., Hobby, M., and Marsham, J. H.: The daytime cycle in dust aerosol direct radiative effects observed in the central Sahara during the Fennec campaign in June 2011, J. Geophys. Res.-Atmos., 119, 13861-13876, doi:10.1002/2014JD022077, 2014.

Biasutti, M., Sobel, A. H., and Camargo, S. J.: The role of the Sahara low in summertime Sahel rainfall variability and change in the CMIP3 models, J. Climate, 22, 5755-5771, doi:10.1175/2009JCLI2969.1, 2009.

Birch, C. E., Parker, D. J., Marsham, J. H., and Devine, G. M.: The effect of orography and surface albedo on stratification in the Saharan atmospheric boundary layer: dynamics and implications for dust transport, J. Geophys. Res.-Atmos., 117, D05105, doi:10.1029/2011JD015965, 2012.

Birch, C. E., Parker, D. J., Marsham, J. H., Copsey, D., and GarciaCarreras, L.: A seamless assessment of the role of convection in the water cycle of the West African Monsoon, J. Geophys. Res.Atmos., 119, 2890-2912, doi:10.1002/2013JD020887, 2014.

Bou Karam, D., Flamant, C., Knippertz, P., Reitebuch, O., Pelon, J., Chong, M., and Dabas, A.: Dust emissions over the Sahel asso- ciated with the West African monsoon intertropical discontinuity region: A representative case-study, Q. J. Roy. Meteor. Soc., 134, 621-634, doi:10.1002/qj.244, 2008.

Bouniol, D., Couvreux, F., Kamsu-Tamo, P.-H., Leplay, M., Guichard, F., Favot, F., and O'Connor, E. J.: Diurnal and Seasonal Cycles of Cloud Occurrences, Types, and Radiative Impact over West Africa, J. Appl. Meteorol. Clim., 51, 534-553, doi:10.1175/JAMC-D-11-051.1, 2012.

Brindley, H. E. and Harries, J. E.: The impact of far i.r. absorption on clear sky greenhouse forcing: sensitivity studies at high spectral resolution, J. Quant. Spectrosc. Ra., 60, 151-180, doi:10.1016/S0022-4073(97)00152-0, 1998.

Charney, C. G.: Dynamics of deserts and drought in the Sahel, Q. J. Roy. Meteor. Soc., 101, 193-202, doi:10.1002/qj.49710142802, 1975.

Chauvin, F., Roehrig, R., and Lafore, J.-P.: Intraseasonal variability of the Saharan heat low and its link with midlatitudes, J. Climate, 23, 2544-2561, doi:10.1175/2010JCLI3093.1, 2010.

Cuesta, J., Marsham, J. H., Parker, D. J., and Flamant, C.: Dynamical mechanisms controlling the vertical redistribution of dust and the thermodynamic structure of the West Saharan Atmospheric Boundary Layer during Summer, Atmos. Sci. Lett., 10, 34-42, doi:10.1002/asl.207, 2009.

Cuesta, J., Lavaysse, C., Flamant, C., Mimouni, M., and Knippertz, P.: Northward bursts of the West African monsoon leading to rainfall over the Hoggar Massif, Algeria, Q. J. Roy. Meteor. Soc., 136, 174-189, doi:10.1002/qj.439, 2010.

Dee, D. P., Uppala, S. M., Simmons, A. J., Berrisford, P., Poli, P., Kobayashi, S., Andrae, U., Balmaseda, M. A., Balsamo, G., Bauer, P., Bechtold, P., Beljaars, A. C. M., van de Berg, L., Bidlot, J., Bormann, N., Delsol, C., Dragani, R., Fuentes, M., Geer, A. J., Haimberger, L., Healy, S. B., Hersbach, H., Hólm, E. V., Isaksen, L., Kållberg, P., Köhler, M., Matricardi, M., McNally, A. P., Monge-Sanz, B. M., Morcrette, J.-J., Park, B.-K., Peubey, C., de Rosnay, P., Tavolato, C., Thépaut, J.-N., and Vitart, F.: The ERA-Interim reanalysis: configuration and performance of the data assimilation system, Q. J. Roy. Meteor. Soc., 137, 553-597, doi:10.1002/qj.828, 2011.

Dewitte, S., Gonzalez, L., Clerbaux, N., Ipe, A., Bertrand, C., and Paepe, B. D.: The Geostationary Earth Radiation Budget Edition 1 data processing algorithms, Adv. Space Res., 41, 1906-1913, doi:10.1016/j.asr.2007.07.042, 2008.

Dolinar, E. K., Dong, X., and Xi, B.: Evaluation and intercomparison of clouds, precipitation, and radiation budgets in recent reanalyses using satellite-surface observations, Clim. Dynam., doi:10.1007/s00382-015-2693-z, online first, 2015.

Dong, B. and Sutton, R.: Dominant role of greenhouse-gas forcing in the recovery of Sahel rainfall, Nature Climate Change, 5, 757760, doi:10.1038/nclimate2664, 2015.

Emmel, C., Knippertz, P., and Schulz, O.: Climatology of convective density currents in the southern foothills of the Atlas Mountains, J. Geophys. Res., 115, D11115, doi:10.1029/2009JD012863, 2010.

Evan, A. T., Flamant, C., Fiedler, S., and Doherty, O.: An analysis of aeolian dust in climate models, Geophys. Res. Lett., 41, 59966001, doi:10.1002/2014GL060545, 2014.

Evan, A. T., Flamant, C., Lavaysse, C., Kocha, C., and Saci, A.: Water Vapor-Forced Greenhouse Warming over the Sahara Desert 
and the Recent Recovery from the Sahelian Drought, J. Climate, 28, 108-123, doi:10.1175/JCLI-D-14-00039.1, 2015.

Garcia-Carreras, L., Marsham, J. H., Parker, D. J., Bain, C. L., Milton, S., Saci, A., Salah-Ferroudj, M., Ouchene, B., and Washington, R.: The impact of convective cold pool outflows on model biases in the Sahara, Geophys. Res. Lett., 40, 1647-1652, doi:10.1002/grl.50239, 2013.

Grams, C. M., Jones, S. C., Marsham, J. H., Parker, D. J., Haywood, J. M., and Heuveline, V.: Atlantic Inflow to the Saharan heat low: Observations and modelling, Q. J. Roy. Meteor. Soc., 136, 125$140,2010$.

Harries, J. E., Russell, J. E., Hanafin, J. A., Brindley, H., Futyan, J., Rufus, J., Kellock, S., Matthews, G., Wrigley, R., Last, A., Mueller, J., Mossavati, R., Ashmall, J., Sawyer, E., Parker, D., Caldwell, M., Allan, P. M., Smith, A., Bates, M. J., Coan, B., Stewart, B. C., Lepine, D. R., Cornwall, L. A., Corney, D. R., Ricketts, M. J., Drummond, D., Smart, D., Cutler, R., Dewitte, S., Clerbaux, N., Gonzalez, L., Ipe, A., Bertrand, C., Joukoff, A., Crommelynck, D., Nelms, N., Llewellyn-Jones, D. T., Butcher, G., Smith, G. L., Szewczyk, Z. P., Mlynczak, P. E., Slingo, A., Allan, R. P., and Ringer, M. A.: The geostationary earth radiation budget project, B. Am. Meteorol. Soc., 86, 945-960, doi:10.1175/BAMS-86-7-945, 2005.

Haywood, J. M., Allan, R. P., Culverwell, I., Slingo, T., Milton, S., Edwards, J., and Clerbaux, N.: Can desert dustexplain the outgoing longwave radiation anomaly over the Sahara during July 2003?, J. Geophys. Res., 110, D05105, doi:10.1029/2004JD005232, 2005.

Heinold, B., Knippertz, P., Marsham, J. H., Fiedler, S., Dixon, N., Schepanski, K., Laurent, B., and Tegen, I.: The Role of Deep Convection and Low-Level Jets for Dust Emission in Summertime West Africa, J. Geophys. Res.-Atmos., 118, 1-16, doi:10.1002/jgrd.50402, 2013.

Holben, B. N., Eck, T. F., Slutsker, I., Tanré, D., Buis, J. P., Setzer, A., Vermote, E., Reagan, J. A., Kaufman, Y. J., Nakajima, T., Lavenu, F., Jankowiak, I., and Smirnov, A.: AERONET - A federated instrument network and data archive for aerosol characterization, Remote Sens. Environ., 66, 1-16, doi:10.1016/S00344257(98)00031-5, 1998.

Lavaysse, C., Flamant, C., Janicot, S., Parker, D. J., Lafore, J.-P., Sultan, B., and Pelon, J.: Seasonal evolution of the West African heat low: a climatological perspective, Clim. Dynam., 33, 313330, 2009.

Lavaysse, C., Flamant, C., Janicot, S., and Knippertz, P.: Links between African easterly waves, midlatitude circulation and intraseasonal pulsations of the West African heat low, Q. J. Roy. Meteor. Soc., 136, 141-158, 2010.

Marsham, J. H., Parker, D. J., Grams, C. M., Taylor, C. M., and Haywood, J. M.: Uplift of Saharan dust south of the intertropical discontinuity, J. Geophys. Res.-Atmos., 113, D21102, doi:10.1029/2008JD009844, 2008.

Marsham, J. H., Knippertz, P., Dixon, N., Parker, D. J., and Lister, G. M. S.: The importance of the representation of deep convection for modeled dust-generating winds over West Africa during summer, Geophys. Res. Lett., 38, L16803, doi:10.1029/2011GL048368, 2011.

Marsham, J. H., Hobby, M., Allen, C. J. T., Banks, J. R., Bart, M., Brooks, B. J., Cavazos-Guerra, C., Engelstaedter, S., Gascoyne, M., Lima, A. R., Martins, J. V., McQuaid, J. B., O’Leary,
A., Ouchene, B., Ouladichir, A., Parker, D. J., Saci, A., SalahFerroudj, M., Todd, M. C., and Washington, R.: Meteorology and dust in the central Sahara: Observations from Fennec supersite-1 during the June 2011 Intensive Observation Period, J. Geophys. Res.-Atmos., 118, 4069-4089, doi:10.1002/jgrd.50211, 2013a.

Marsham, J. H., Dixon, N., Garcia-Carreras, L., Lister, G. M. S., Parker, D. J., Knippertz, P., and Birch, C. E.: The role of moist convection in the West African monsoon system - insights from continental-scale convection-permitting simulations, Geophys. Res. Lett., 40, 1843-1849, doi:10.1002/grl.50347, 2013b.

Martin, E. R. and Thorncroft, C. D.: The impact of the AMO on the West African monsoon annual cycle, Q. J. Roy. Meteor. Soc., 140, 31-46, doi:10.1002/qj.2107, 2014.

Martin, E. R., Thorncroft, C. D., and Booth, B. B.: The multidecadal Atlantic SST-Sahel rainfall teleconnection in CMIP5 simulations, J. Climate, 27, 784-805, doi:10.1175/JCLI-D-13-00242.1, 2014.

Parker, D. J., Thorncroft, C. D., Burton, R. R., and Diongue-Niang, A.: Analysis of the African easterly jet, using aircraft observations from the JET2000 experiment, Q. J. Roy. Meteor. Soc., 131, 1461-1482, doi:10.1256/qj.03.189, 2005.

Peyrillé, P. and Lafore, J.-P.: An idealized two-dimensional framework to study the West African monsoon. Part II: Large-scale advection and the diurnal cycle, J. Atmos. Sci., 64, 2783-2803, doi:10.1175/JAS4052.1, 2007.

Roberts, A., Marsham, J. H., and Knippertz, P.: Disagreements in Low-level Moisture between (Re)Analyses over Summertime West Africa, Mon. Weather Rev., 143, 1193-1211, doi:10.1175/MWR-D-14-00218.1, 2015.

Roehrig, R., Bouniol, D., Guichard, F., Hourdin, F., and Redelsperger, J. L.: The present and future of the West African monsoon: A process-oriented assessment of CMIP5 simulations along the AMMA transect, J. Climate, 26, 6471-6505, 2013.

Ryder, C. L., Highwood, E. J., Rosenberg, P. D., Trembath, J., Brooke, J. K., Bart, M., Dean, A., Crosier, J., Dorsey, J., Brindley, H., Banks, J., Marsham, J. H., McQuaid, J. B., Sodemann, H., and Washington, R.: Optical properties of Saharan dust aerosol and contribution from the coarse mode as measured during the Fennec 2011 aircraft campaign, Atmos. Chem. Phys., 13, 303325, doi:10.5194/acp-13-303-2013, 2013.

Ryder, C. L., McQuaid, J. B., Flamant, C., Rosenberg, P. D., Washington, R., Brindley, H. E., Highwood, E. J., Marsham, J. H., Parker, D. J., Todd, M. C., Banks, J. R., Brooke, J. K., Engelstaedter, S., Estelles, V., Formenti, P., Garcia-Carreras, L., Kocha, C., Marenco, F., Sodemann, H., Allen, C. J. T., Bourdon, A., Bart, M., Cavazos-Guerra, C., Chevaillier, S., Crosier, J., Darbyshire, E., Dean, A. R., Dorsey, J. R., Kent, J., O’Sullivan, D., Schepanski, K., Szpek, K., Trembath, J., and Woolley, A.: Advances in understanding mineral dust and boundary layer processes over the Sahara from Fennec aircraft observations, Atmos. Chem. Phys., 15, 8479-8520, doi:10.5194/acp-15-84792015, 2015.

Slingo, A., Ackerman, T. P., Allan, R. P., Kassianov, E. I., McFarlane, S. A., Robinson, G. J., Barnard, J. C., Miller, M. A., Harries, J. E., Russell, J. E., and Dewitte, S.: Observations of the impact of a major Saharan dust storm on the atmospheric radiation balance, Geophys. Res. Lett., 33, L24817, doi:10.1029/2006GL027869, 2006. 
Slingo, A., White, H. E., Bharmal, N. A., and Robinson, G. J.: Overview of observations from the RADAGAST experiment in Niamey, Niger: 2. Radiative fluxes and divergences, J. Geophys. Res., 114, D00E04, doi:10.1029/2008JD010497, 2009.

Stein, T. H. M., Parker, D. J., Delanoë, J., Dixon, N. S., Hogan, R. J., Knippertz P., and Marsham, J. H.: Vertical cloud structure for the West African monsoon: A four-year climatology using CloudSat and CALIPSO, J. Geophys. Res.-Atmos., 116, D22205, doi:10.1029/2011JD016029, 2011.

Stein, T. H. M., Parker, D. J., Hogan, R. J., Birch, C. E., Holloway, C. E., Lister, G. M. S., Marsham, J. H., and Woolnough, S. J.: The representation of the West African monsoon vertical cloud structure in the Met Office Unified Model: an evaluation with CloudSat, Q. J. Roy. Meteor. Soc., 141, 3312-3324, doi:10.1002/qj.2614, 2015.

Sultan, B. and Janicot, S.: The West African Monsoon dynamics. part II: the "preonset" and "onset" of the summer monsoon, J. Climate, 16, 3407-3427, 2003.

Thorncroft, C. D. and Blackburn, M.: Maintenance of the African easterly jet, Q. J. Roy. Meteor. Soc., 125, 763-786, doi:10.1002/qj.49712555502, 1999.

Todd, M. C., Allen, C. J. T, Bart, M., Bechir, M., Bentefouet, J., Brooks, B. J., Cavazos-Guerra, C., Clovis, T., Deyane, S., Dieh, M., Engelstaedter, S., Flamant, C., Garcia-Carreras, L., Gandega, A., Gascoyne, M., Hobby, M., Kocha, C., Lavaysse, C., Marsham, J. H., Martins, J. V., McQuaid, J.B., Ngamini, J. B., Parker, D. J., Podvin, T., Rocha-Lima, A., Traore, S., Wang, Y., and Washington, R.: Meteorological and dust aerosol conditions over the Western Saharan region observed at Fennec supersite-2 during the Intensive Observation Period in June 2011, J. Geophys. Res.-Atmos., 118, 8426-8447, doi:10.1002/jgrd.50470, 2013.
Washington, R., Flamant, C., Parker, D. J., Marsham, J., McQuaid, J., Brindley, H., Todd, M., Highwood, E., Ryder, C., Chaboureau, J.-P., Kocha, C., Bechir, M., and Saci, A.: Fennec - The Saharan Climate System, CLIVAR Exchanges, 17, 31-32, 2012.

Xue, Y. K., De Sales, F., Lau, W. K.-M., Boone, A., Feng J. M., Dirmeyer, P., Guo, Z. C., Kim, K.-M., Kitoh, A., Kumar, V., Poccard-Leclercq, I., Mahowald, N., Moufouma-Okia, W., Pegion, P., Rowell, D. P., Schemm, J., Schubert, S. D., Sealy, A., Thiaw, W. M., Vintzileos, A., Williams, S. F., and Wu, M.L. C.: Intercomparison and analyses of the climatology of the West African Monsoon in the West African Monsoon Modeling and Evaluation project (WAMME) first model intercomparison experiment, Clim. Dynam., 35, 3-27, doi:10.1007/s00382-0100778-2, 2010.

Yang, E.-S., Gupta, P., and Sundar, A. C.: Net radiative effect of dust aerosols from satellite measurements over Sahara, Geophys. Res. Lett., 36, L18812, doi:10.1029/2009GL039801, 2009. 